\title{
River water quality in the northern sugarcane-producing regions of South Africa and implications for irrigation: A scoping study
}

\author{
Michael van der Laan ${ }^{1,3 *}$, Rianto van Antwerpen ${ }^{1}$ and Keith L Bristow ${ }^{2,3}$ \\ ${ }^{1}$ South African Sugarcane Research Institute, Private Bag X02, Mount Edgecombe 4300, South Africa \\ ${ }^{2}$ CSIRO Sustainable Agriculture National Research Flagship, CSIRO Land and Water, PMB Aitkenvale, \\ Townsville, QLD 4814, Australia \\ ${ }^{3}$ University of Pretoria Water Institute and Department of Plant Production and Soil Science, University of Pretoria, \\ Private Bag X20 Hatfield, Pretoria 0028, South Africa
}

\begin{abstract}
Sustainable cultivation of crops under irrigation requires water of appropriate quality, especially with regards to salinity and sodicity. Agriculture can impact negatively on water quality, often through the export of nutrients (particularly nitrogen $(\mathrm{N})$ and phosphorus (P)) from the root zone, resulting in eutrophication of surface water and pollution of groundwater. Sugarcane is the major irrigated crop with regards to area cultivated in the Crocodile, Komati-Lomati and Pongola River catchments. Increasing demand for and use of water resources in these catchments has led to concerns about deterioration in water quality. In this study, chemical water quality data obtained from the South African Department of Water Affairs was used to assess the quality of river water in the above catchments. Electrical conductivity (EC) data show an increase in salt concentration along the river course as a result of various anthropogenic activities in the catchment. Irrigators located further downstream will therefore generally have to pay more attention to the quality of their irrigation water and on-farm salinity management. For the lower parts of the Komati-Lomati and Pongola River catchments, hazards due to sodicity will also need attention. Interestingly, acidifying effects of mine water drainage are potentially being countered by high salt input from agricultural return flow. Nutrient enrichment was evident at many of the river sampling points. Increasing salt, sodicity, $\mathrm{N}$ and $\mathrm{P}$ over time for most of the rivers studied is also a concern that requires action to ensure the sustainability of irrigation activities in these catchments. More intensive monitoring, including measurement of organic $\mathrm{N}$ and $\mathrm{P}$ fractions, is recommended to improve understanding of the contribution of different anthropogenic activities to river water pollution and to develop effective mitigation strategies.
\end{abstract}

Keywords: salinity, sodicity, nitrogen, phosphorus, Crocodile, Komati-Lomati, Pongola River catchments

\section{Introduction}

Increasing water scarcity in South Africa requires optimal management of this critical resource. Further development along our important rivers can be expected to impact water quality negatively. At a specific point along a river, the quality of water reflects several major influences, including basin lithology, climatic conditions and atmospheric and anthropogenic inputs (Bricker and Jones, 1995; Shrestha and Kazama, 2007). Anthropogenic inputs can be fairly constant in time, for example, industrial or municipal wastewater discharge, or highly correlated to climate, for example, discharges via agricultural runoff. Activities that cause stream flow reduction, such as commercial forestry, can also impact negatively on water quality by reducing the dilution capacity of a waterway. Increased crop production activities within a catchment often result in higher nutrient concentrations in rivers and impoundments (Heithwaite and Jones, 1996). For example, Matson et al. (1997) observed that nitrate $\left(\mathrm{NO}_{3}{ }^{-}\right)$pollution is common in agricultural regions throughout the world. This enrichment can result in eutrophication of these systems. The Organisation for Economic Co-operation and Development (OECD, 1982),

\footnotetext{
* To whom all correspondence should be addressed.

魚 +31 508 7449; fax: +31 508 7597;

e-mail: michael.vanderlaan@sugar.org.za

Received 16 February 2011; accepted in revised form 14 December 2011.
}

define the eutrophication process as '...the nutrient enrichment of waters which results in the stimulation of an array of symptomatic changes, amongst which increased production of algae and aquatic macrophytes, deterioration of water quality and other symptomatic changes are found to be undesirable and interfere with water uses'.

In irrigated agriculture, water of an acceptable quality is required for profitable and sustainable crop production. Irrigating with water high in salts can reduce yields significantly, especially in cases where there is poor soil drainage. As crops transpire irrigated water, salts are left behind inevitably leading to a build-up in their concentration. Sustainable production requires the periodic export of this salt from the root zone to prevent salinity problems. This is either achieved passively by rainfall or actively through the application of irrigation volumes in excess of the soil water holding capacity, often referred to as the 'leaching requirement' (Rhoades, 1974). The higher the salt volume being added with the irrigation water, the greater will be the leaching requirement and resultant salt concentration in the draining water. When these salts are washed from agricultural lands back into waterways, a subsequent deterioration in quality of these receiving water bodies can be expected. In addition, when irrigation water has a high proportion of sodium $(\mathrm{Na})$ cations in relation to magnesium (Mg) and calcium (Ca) cations, a sodicity hazard is presented as high $\mathrm{Na}$ levels can lead to clay particle de-flocculation and impede infiltration (Suarez et al., 2006). 
Sugarcane production in South Africa occurs exclusively in the eastern regions of the country. Rainfed production predominates in the regions south of the Tugela River (29²'s, $31^{\circ} 29^{\prime} \mathrm{E}$ ), while irrigated production is more common north of the Tugela. In the Malelane and Komatipoort regions, the major sources of irrigation water are the Crocodile, Lomati and Komati Rivers and some of their tributaries, while the source of irrigation water in the Pongola region is water from the Pongola and Bivane Rivers. Because these rivers flow into neighbouring countries (Swaziland and Mozambique), they are considered transboundary rivers, making their management internationally significant. Tell-tale signs of increasing salinity in some irrigated sugarcane regions in South Africa have recently been observed, including increased blockages and concentrated salt rings around the emitters of drip irrigation systems and salt lines along the sidewalls of waterways. Driven by these and other water pollution concerns, this paper makes use of data obtained from the South African Department of Water Affairs for the period 1999-2009, as well as other studies (Johnston, 1976; Meyer and Van Antwerpen, 1995), to analyse the current status and long-term trends in river water chemistry for the catchments mentioned above.

\section{Catchment descriptions}

\section{Crocodile River catchment}

The following summary of the characteristics and hydrology of the Crocodile River catchment was obtained from Deksissa et al. (2003). The main-stem length of the Crocodile River is $320 \mathrm{~km}$, draining an area of $10450 \mathrm{~km}^{2}$. Mean annual precipitation for the catchment is $880 \mathrm{~mm}$, varying from $1200 \mathrm{~mm}$ in the western and central parts to $600 \mathrm{~mm}$ in the drier Lowveld in the east. Most rainfall occurs in the summer months between November and March. Reduced flows as a result of irrigation abstraction and afforestation have been observed in the Crocodile River and its tributaries. The Kwena Dam (167 $\times 10^{6} \mathrm{~m}^{3}$ capacity) plays a significant role in regulating river flow. In order to supply water to irrigation farmers along the middle and lower reaches of the river and to assist in flushing out wastewater effluent discharge, water is released from the dam in such a way as to ensure a minimum flow of $7 \mathrm{~m}^{3} \cdot \mathrm{s}^{-1}$ during the winter months. Low river flow due to anthropogenic activities combined with high pollutant loads from point and non-point sources have resulted in a deterioration of water quality, with salinity and eutrophication recognised as the major water quality problems for this river (Deksissa et al., 2003). The major crops cultivated in the Crocodile River catchment include citrus, mangoes, bananas, avocadoes (Olbrich and Hassan, 1999) and about 12500 ha of irrigated sugarcane. The region also contains around $1775 \mathrm{~km}^{2}$ of exotic forests (DWAF, 2004). This catchment is recognised as the most water-stressed catchment in South Africa, a major concern considering the increasing number of people who depend on it for their livelihood, including a large demand for water by emerging farmers. Full implementation of the 'ecological Reserve' will also compete for water with existing and new uses (DWAF, 2004).

\section{Komati-Lomati River catchment}

The following description is based on Conley (1996) and Tlou and Mallory (2006). The Komati-Lomati River catchment is located within the $50000 \mathrm{~km}^{2}$ Inkomati River Basin, of which $63 \%$ of the area of this basin is in South Africa, 5\% in Swaziland and 32\% in Mozambique. Mean annual precipitation for the region is about $760 \mathrm{~mm}$. The Komati River originates in the South African interior and flows towards the east into the Nooitgedacht Dam $\left(78.4 \times 10^{6} \mathrm{~m}^{3}\right.$ capacity). From here it flows through the northern part of Swaziland into the Maguga Dam $\left(332 \times 10^{6} \mathrm{~m}^{3}\right.$ capacity) before returning to South Africa and finally flowing into Mozambique. The Lomati River (also referred to as the Mlumati) originates in Swaziland, and flows into the Driekoppies Dam $\left(251 \times 10^{6} \mathrm{~m}^{3}\right.$ capacity) before its confluence with the Komati River. Much of the upper reaches of the catchment is under commercial forestry. Irrigated sugarcane is cultivated on 26000 ha in South Africa and 29000 ha in Swaziland. Other major irrigated crops in the catchment include bananas, litchis, mangoes and papaya, and some maize and wheat is also grown. As there is no industry upstream of the Lomati and Komati Rivers there are reported to be few water quality problems, but numerous weirs and low flow in downstream sections of the Komati interfere with the migration of fish, of which there is a rich diversity in the area (Faysse and Gumbo, 2004). Dramatic increases in irrigation water demand are being observed in this region as a result of growth in the emerging farmer sector (DWAF, 2004).

\section{Pongola River catchment}

The following description was obtained from DWA (2009). The Pongola River originates on the interior plateau at about 1800 metres above sea level and flows eastwards. Mean annual precipitation for the region is about $610 \mathrm{~mm}$. Following the confluence with the Bivane River, it flows through hilly terrain where it is joined by several smaller tributaries. Further upstream in the Pongola catchment, an estimated area of 480 $\mathrm{km}^{2}$ is under afforestation, which influences reliability of water supply to downstream irrigators. The Bivane Dam $\left(115 \times 10^{6}\right.$ $\mathrm{m}^{3}$ capacity) (previously named Paris) on the Bivane River was constructed by the Impala Water Users Association (WUA) to improve the reliability of supply for irrigators. In the Middle Pongola sub-catchment, about 16000 ha is under sugarcane and another 1000 ha is under irrigated citrus, mangoes and vegetables. Another 3400 ha of irrigated sugarcane and cotton has been established by small farmer co-operatives downstream of the Jozini Dam (2 $267 \times 10^{6} \mathrm{~m}^{3}$ capacity) (previously named Pongolapoort) which is located in the lower Pongola sub-catchment at the end of a narrow gorge in the Lebombo Mountains. Thereafter the river flows into Mozambique. According to DWA (2009), water quality between the Impala Irrigation Scheme and the Jozini Dam is poor due to irrigation return flows.

\section{Materials and methods}

\section{Monitoring locations and measurements}

Water quality data for the period 1999-2009 were obtained from the South African Department of Water Affairs (DWA) (formerly the Department of Water Affairs and Forestry (DWAF)). Electrical conductivity (EC), sodium adsorption ratio (SAR), $\mathrm{pH}$, nitrate- + nitrite-nitrogen $\left(\mathrm{NO}_{3}+\mathrm{NO}_{2}-\mathrm{N}\right)$, total inorganic $\mathrm{N}$ (nitrate- + nitrite- + ammonium-N) and phosphatephosphorus $\left(\mathrm{PO}_{4}-\mathrm{P}\right)$ data were considered. Chloride $(\mathrm{Cl})$ levels for the rivers analysed were always well below potentially problematic levels $\left(<105 \mathrm{mg} \cdot \ell^{-1} \mathrm{Cl}\right)$ and are therefore not reported in 


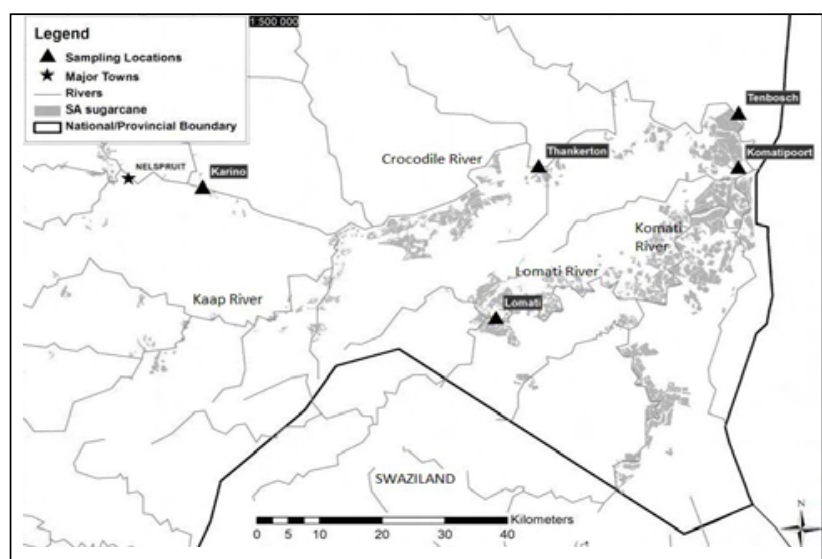

(a)

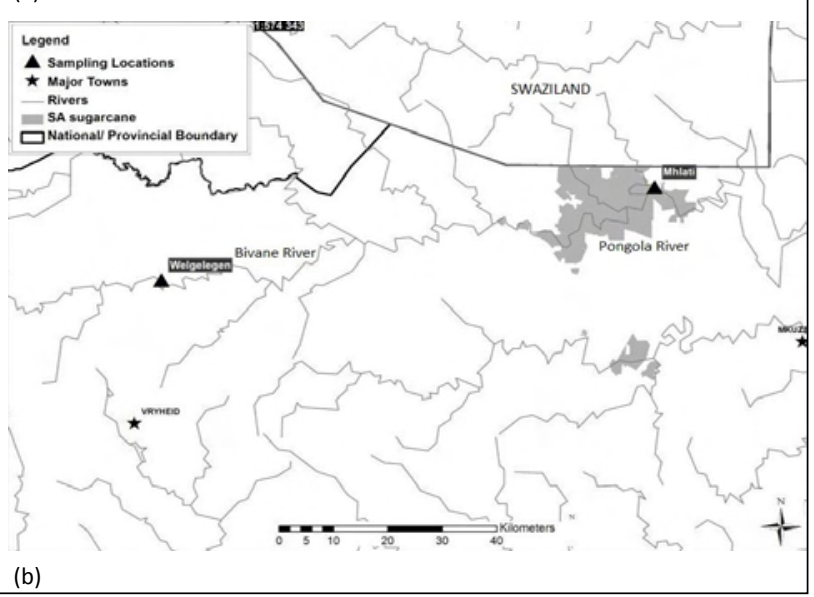

Figure 1

Areas under sugarcane production (shaded areas), important rivers and water quality sampling points (identified by triangles) in the Crocodile and Komati-Lomati River catchments (a) and Pongola River catchment (b).

this study. Boron concentrations are not routinely analysed so this element was also excluded from the present analysis. For the Crocodile River catchment, data from the Crocodile

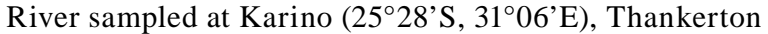

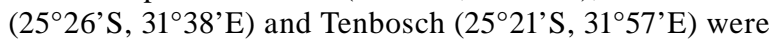
used. For the Komati-Lomati catchment, data for the Lomati River sampled at Lomati (2540'S, 31 $34^{\circ}$ 'E) and the Komati

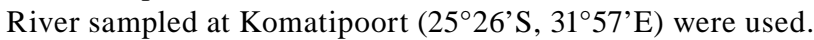
For the Pongola River catchment, data for the Bivane River

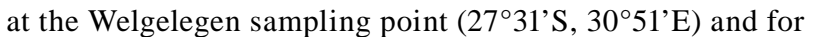
the Pongola River at the Mhlati sampling point $\left(27^{\circ} 21^{\prime} \mathrm{S}\right.$, $31^{\circ} 46^{\prime} \mathrm{E}$ ) were used. The catchments described above, areas under sugarcane and sampling points are presented in Fig. 1. Chemical water quality data for spring (1 Sep 12 Oct), summer (13 Oct - 28/29 Feb), autumn (1 Mar - 12 Apr) and winter (13 Apr - 31 Aug) were assessed and are reported. River water flow rate data were considered but are not discussed, as the focus in this paper is on pollutant concentration rather than on total pollutant load.

Previous investigations into river water quality for the northern irrigated sugarcane regions of South Africa have been conducted by Johnston (1976) and Meyer and Van Antwerpen (1995). Johnston (1976) used data obtained from samples collected on a monthly basis from 1972-1974, while Meyer and Van Antwerpen (1995) used data obtained from the Department of Water Affairs database for the period 19831993. Results from this study using data from 1999-2009 enable analysis of longer-term trends.

\section{Water quality data}

Electrical conductivity is most commonly used as an indicator of salinity and irrigation water quality classifications for this parameter are given in Table 1. Soils with high Na can become sodic and water infiltration problems may occur due to clay dispersion caused by the Na. The SAR gives the levels of $\mathrm{Na}$ cations relative to $\mathrm{Ca}$ and $\mathrm{Mg}$ cations and is used to asses sodicity risk (Table 1).

Nitrogen and $\mathrm{P}$ are the primary nutrients causing eutrophication because they are most often the limiting factors for algal growth. Depending on the level of enrichment, water bodies can be classified as oligotrophic (low nutrient levels and no quality problems), mesotrophic (intermediate nutrient levels with emerging signs of quality problems), eutrophic (high nutrient levels and frequent quality problems) or hypertrophic (excessive nutrient levels and almost continuous quality problems) (Table 2) (Walmsley, 2000). Site-specific conditions are critically important in determining the influence of $\mathrm{N}$ on eutrophication, with concentrations of $0.4-1.0 \mathrm{mg} \cdot \ell^{-1} \mathrm{~N}$ generally considered low enough to limit eutrophication (MacKay et al., 1995). In freshwater $\mathrm{P}$ is important as it limits rate processes and total biomass, and $\mathrm{N}$ availability will largely determine the species composition of algal blooms; while in marine environments $\mathrm{N}$ becomes the growth-limiting nutrient (Young et al., 1996). The reduction of $P$ availability in surface waters is recognised as the only practical way to combat eutrophication (Walmsley, 2000), and P levels for trophic status classification are presented in Table 2. The South African DWA has set effluent discharge standards (Table 2) (DWAF, 1996) in a source-directed approach to eutrophication management (Walmsley, 2000). The extent of catchment development and disturbance can be well reflected by $\mathrm{NO}_{3}^{-}$levels, and the correlation between $\mathrm{NO}_{3}^{-}$in rivers and human population in that catchment is well established (Peierls et al., 1991; Brodie and Mitchell,

\begin{tabular}{|c|c|c|c|c|}
\hline \multicolumn{5}{|c|}{$\begin{array}{c}\text { Table } 1 \\
\text { Irrigation water classes for electrical conductivity (EC) } \\
\text { and sodium adsorption ratio (SAR) (from Koegelenberg, } \\
2004)\end{array}$} \\
\hline \multirow[t]{2}{*}{ Constituent } & \multicolumn{4}{|c|}{ Fitness for use } \\
\hline & Good & Fair & Marginal & Unacceptable \\
\hline $\mathrm{EC}\left(\mathrm{mS} \cdot \mathrm{m}^{-1}\right)$ & $0-40$ & $40-90$ & $90-270$ & $>270$ \\
\hline SAR & $0-1.5$ & $1.5-3.0$ & $3.0-5.0$ & $>5.0$ \\
\hline
\end{tabular}

\section{TABLE 2}

South African effluent discharge standards and phosphorus levels for trophic status classification

\begin{tabular}{|l|c|c|c|c|c|}
\hline & $\begin{array}{c}\text { Effluent discharge } \\
\text { standard }\end{array}$ & Oligotrophic & Mesotrophic & Eutrophic & Hyper-eutrophic \\
\hline Inorganic nitrogen $\left(\mathrm{mg} \cdot \ell^{-1}\right)$ & $<10$ & - & - & - & - \\
\hline Phosphorus $\left(\mathrm{mg} \cdot \ell^{-1}\right)$ & $<1$ & $0.004-0.010$ & $0.010-0.035$ & $0.035-0.100$ & $>0.100$ \\
\hline
\end{tabular}



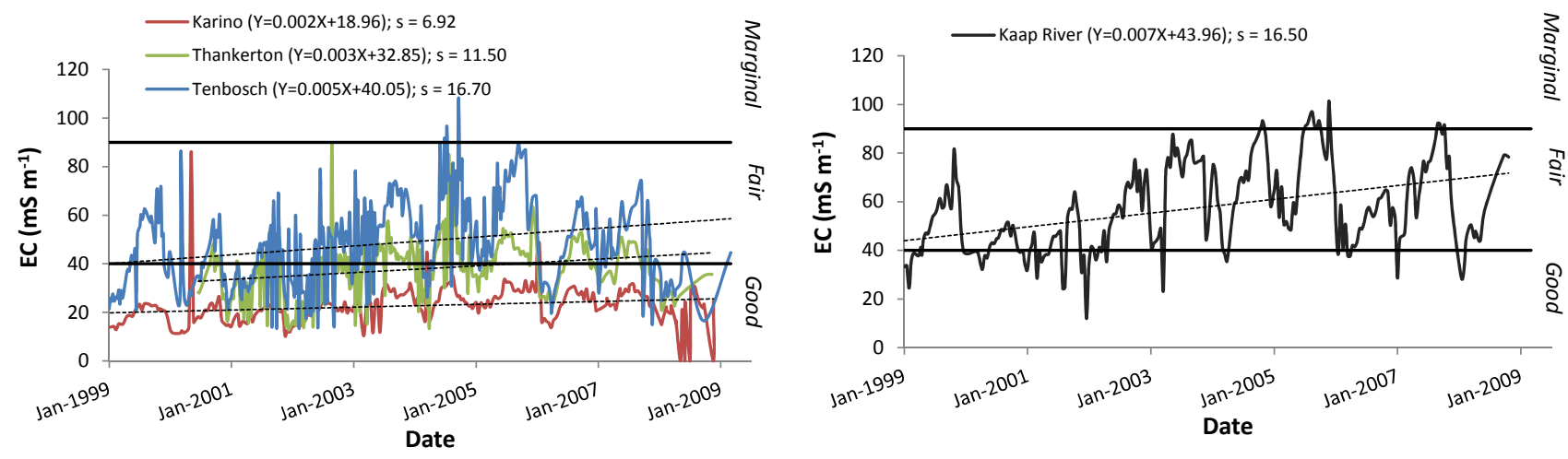

Figure 2

Crocodile River electrical conductivity (EC) measured at Karino, Thankerton and Tenbosch (left) and Kaap River EC (right) for the period 1999-2009 (black horizontal lines separate different salinity categories; linear regression equations shown, $X=$ time, $Y=E C ; s=$ standard error about the regression line)

\begin{tabular}{|c|c|c|c|c|c|c|c|c|c|c|c|c|c|c|c|c|}
\hline \multicolumn{17}{|c|}{$\begin{array}{c}\text { TABLE } 3 \\
\text { Water quality data for the Crocodile River measured at Karino, Thankerton and Tenbsoch for the period 1999-2009 }\end{array}$} \\
\hline \multirow{3}{*}{\multicolumn{2}{|c|}{ Paramaters }} & \multicolumn{15}{|c|}{ Crocodile River Catchment } \\
\hline & & \multicolumn{5}{|c|}{ Karino } & \multicolumn{5}{|c|}{ Thankerton } & \multicolumn{5}{|c|}{ Tenbosch } \\
\hline & & Spring & \begin{tabular}{|l|} 
Summer \\
\end{tabular} & \begin{tabular}{|l|} 
Autumn \\
\end{tabular} & Winter & nual & Spring & Summer & \begin{tabular}{|l|} 
Autumn \\
\end{tabular} & Winter & Annual & Spring & Summer & \begin{tabular}{|l|} 
Autumn \\
\end{tabular} & Winter & Annual \\
\hline EC & Range & $21-30$ & $10-48$ & $10-45$ & $12-86$ & $10-86$ & $22-56$ & $13-63$ & $14-67$ & $14-89$ & $13-89$ & 14-108 & $14-87$ & 18-84 & $14-97$ & $14-108$ \\
\hline \multirow[t]{4}{*}{$\left(\mathrm{mS} \cdot \mathrm{m}^{-1}\right)$} & Mean & 25 & 22 & 19 & 25 & 23 & 42 & 34 & 30 & 42 & 38 & 58 & 45 & 36 & 52 & 48 \\
\hline & S.D. & 3 & 6 & 6 & 8 & 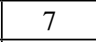 & 8 & 10 & 11 & 12 & 12 & 21 & 15 & 14 & 10 & 17 \\
\hline & Class & ood & Good & Good & Good & Good & Fair & Good & Good & Fair & Good & $\mathrm{Fa}$ & Fair & Good & Fair & Fair \\
\hline & & \multicolumn{5}{|c|}{$\mathrm{n}=233$} & \multicolumn{5}{|c|}{$\mathrm{n}=313$} & \multicolumn{5}{|c|}{$\mathrm{n}=380$} \\
\hline \multirow[t]{5}{*}{ SAR } & Range & $0.4-0.7$ & \begin{tabular}{|l|}
$0.3-0.9$ \\
\end{tabular} & $0.4-0.6$ & $0.2-0.8$ & $0.2-0.9$ & $0.4-2.6$ & \begin{tabular}{|l|l|}
$0.3-1.5$ \\
\end{tabular} & $0.2-1.7$ & $0.3-3.7$ & $0.2-3.7$ & $0.2-2.8$ & \begin{tabular}{|l}
$0.6-3.1$ \\
\end{tabular} & 0.4-2.5 & $0.2-3.8$ & $0.2-3.8$ \\
\hline & Mean & 0.5 & 0.5 & 0.5 & 0.6 & 5 & 1 & 0.9 & 0.8 & 1.1 & 1 & 1.5 & 1.3 & 1.1 & 1.4 & 1.3 \\
\hline & S.D. & 1 & 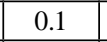 & 0.06 & 0 & & 4 & 3 & 0.3 & 4 & 0.4 & 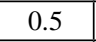 & 4 & 1.4 & 5 & 0.5 \\
\hline & Class & od & Good & Good & Good & Good & Good & Good & Good & Good & Good & $\mathrm{Fa}$ & Good & Good & Good & Good \\
\hline & & \multicolumn{5}{|c|}{$\mathrm{n}=216$} & \multicolumn{5}{|c|}{$\mathrm{n}=311$} & \multicolumn{5}{|c|}{$\mathrm{n}=378$} \\
\hline \multirow[t]{4}{*}{$\mathrm{pH}$} & Range & $6.9-8.2$ & \begin{tabular}{|l|}
$7.1-8.2$ \\
\end{tabular} & $7.2-8.1$ & 6.9-8.3 & 6.9-8.3 & 7.4-8.6 & \begin{tabular}{|l|l|}
$7.0-8.5$ \\
\end{tabular} & $7.0-8.6$ & $7.0-8.5$ & 7.0-8.6 & \begin{tabular}{|c|}
$7.8-9.0$ \\
\end{tabular} & $7.4-9.2$ & 7.3-8.8 & 7.5-8.9 & $7.3-9.2$ \\
\hline & Mean & 7.8 & 7.8 & 7.6 & 7.8 & 7.8 & 8.2 & 8 & 7.9 & 8.1 & 8.1 & 8.3 & 8.2 & 8.1 & 8.3 & 8.2 \\
\hline & S.D. & 0 & 0.2 & 0.2 & 0.2 & 0. & 2 & 0.3 & 0.3 & 0.2 & 0.3 & 7 & 0.2 & 0.3 & 0.2 & 0.3 \\
\hline & & \multicolumn{5}{|c|}{$n=243$} & \multicolumn{5}{|c|}{$\mathrm{n}=313$} & \multicolumn{5}{|c|}{$\mathrm{n}=380$} \\
\hline \multirow[t]{4}{*}{$\begin{array}{l}\mathrm{NO}_{3}+\mathrm{NO}_{2}-\mathrm{N} \\
\left(\mathrm{mg} \cdot \ell^{-1}\right)\end{array}$} & Range & $\begin{array}{c}0.25- \\
0.89\end{array}$ & $\begin{array}{c}0.02- \\
1.19\end{array}$ & \begin{tabular}{c|c}
$0.06-$ \\
1.00
\end{tabular} & \begin{tabular}{c|c|c}
$0.07-$ \\
1.39
\end{tabular} & $\begin{array}{c}0.02- \\
1.39\end{array}$ & $\begin{array}{c}0.04- \\
1.32\end{array}$ & $\begin{array}{c}0.02- \\
1.10\end{array}$ & $\begin{array}{c}0.06- \\
0.88\end{array}$ & $\begin{array}{c}0.02- \\
1.30\end{array}$ & $\begin{array}{l}0.02- \\
1.30\end{array}$ & \begin{tabular}{l|}
$0.02-$ \\
0.68
\end{tabular} & $\begin{array}{l}0.02- \\
1.00\end{array}$ & $\begin{array}{l}0.02- \\
1.26\end{array}$ & $\begin{array}{c}0.02- \\
1.74\end{array}$ & $\begin{array}{l}0.02- \\
1.74\end{array}$ \\
\hline & \begin{tabular}{|l|} 
Mean \\
\end{tabular} & 0.51 & 0.49 & 0.49 & 0.64 & 0.55 & 0.47 & 0.48 & 0.53 & 0.61 & 0.54 & 0.24 & 0.33 & 0.46 & 0.47 & 0.39 \\
\hline & S.D. & 0.19 & 0.26 & 0.22 & 0.26 & 0.25 & 0.29 & 0.27 & 0.200 & 0.26 & 0.27 & 0.20 & 0.24 & 0.24 & 0.30 & 0.27 \\
\hline & & \multicolumn{5}{|c|}{$\mathrm{n}=240$} & \multicolumn{5}{|c|}{$\mathrm{n}=313$} & \multicolumn{5}{|c|}{$\mathrm{n}=380$} \\
\hline \multirow[t]{4}{*}{$\begin{array}{l}\text { Inorganic N } \\
\left(\mathrm{mg} \cdot \ell^{-1}\right)\end{array}$} & Range & $\begin{array}{c}0.27- \\
0.96\end{array}$ & $\begin{array}{l}0.00- \\
2.17\end{array}$ & $\begin{array}{c}0.08- \\
1.44\end{array}$ & $\begin{array}{c}0.00- \\
1.57\end{array}$ & $\begin{array}{l}0.00- \\
2.17\end{array}$ & $\begin{array}{c}0.06- \\
1.42\end{array}$ & $\begin{array}{l}0.04- \\
1.24\end{array}$ & $\begin{array}{c}0.15- \\
0.91\end{array}$ & $\begin{array}{c}0.04- \\
1.39\end{array}$ & $\begin{array}{l}0.04- \\
1.42\end{array}$ & \begin{tabular}{c|}
$0.40-$ \\
0.77
\end{tabular} & $\begin{array}{c}0.04- \\
1.02\end{array}$ & $\begin{array}{l}0.03- \\
1.29\end{array}$ & \begin{tabular}{c|}
$0.04-$ \\
1.76
\end{tabular} & $\begin{array}{l}0.03- \\
1.76\end{array}$ \\
\hline & \begin{tabular}{|l|} 
Mean \\
\end{tabular} & 0.57 & 0.56 & 0.59 & 0.69 & 0.62 & 0.52 & 0.53 & 0.58 & 0.66 & 0.58 & 0.29 & 0.38 & 0.5 & 0.51 & 0.44 \\
\hline & S.D. & 0.22 & 0.33 & 0.27 & 0.33 & 0.32 & 0.30 & 0.30 & 0.20 & 0.27 & 0.28 & 0.21 & 0.24 & 0.24 & 0.30 & 0.27 \\
\hline & & \multicolumn{5}{|c|}{$n=246$} & \multicolumn{5}{|c|}{$\mathrm{n}=313$} & \multicolumn{5}{|c|}{$\mathrm{n}=380$} \\
\hline $\begin{array}{l}\mathrm{PO}_{4}-\mathrm{P} \\
\left(\mathrm{mg} \cdot \ell^{-1}\right)\end{array}$ & Range & $\begin{array}{c}0.006- \\
0.115\end{array}$ & $\begin{array}{c}0.006- \\
0.262\end{array}$ & \begin{tabular}{|c|}
$0.012-$ \\
0.286 \\
\end{tabular} & \begin{tabular}{|c|}
$0.006-$ \\
0.309
\end{tabular} & \begin{tabular}{|c|}
$0.006-$ \\
0.309
\end{tabular} & $\begin{array}{l}0.12- \\
0.098\end{array}$ & \begin{tabular}{|c|}
$0.006-$ \\
0.332
\end{tabular} & $\begin{array}{c}0.012- \\
0.170\end{array}$ & $\begin{array}{c}0.006- \\
0.135\end{array}$ & $\begin{array}{l}0.006- \\
0.332\end{array}$ & $\begin{array}{c}0.006- \\
0.053\end{array}$ & \begin{tabular}{|c|}
$0.006-$ \\
0.230
\end{tabular} & \begin{tabular}{|c|}
$0.012-$ \\
0.108 \\
\end{tabular} & $\begin{array}{c}0.003- \\
0.119\end{array}$ & $\begin{array}{c}0.003- \\
0.231\end{array}$ \\
\hline & \begin{tabular}{|l|} 
Mean \\
\end{tabular} & 0.053 & 0.045 & 0.059 & 0.064 & 0.055 & 0.037 & 0.045 & 0.047 & 0.038 & 0.042 & 0.024 & 0.035 & 0.041 & 0.028 & 0.032 \\
\hline & S.D. & 0.030 & 0.034 & \begin{tabular}{|l|}
0.067 \\
\end{tabular} & 0.052 & 0.047 & 0.019 & 0.035 & 0.029 & 0.022 & 0.030 & 0.018 & 0.028 & 0.019 & 0.017 & 0.022 \\
\hline & & & & $\mathrm{n}=234$ & & & & & $\mathrm{n}=313$ & & & & & $\mathrm{n}=380$ & & \\
\hline
\end{tabular}

S.D. = standard deviation

$n=$ number of observations

2005; Kroon and Brodie, 2009). For this reason $\mathrm{NO}_{3}-\mathrm{N}$ and $\mathrm{NO}_{2}-\mathrm{N}$ data are also presented.

For graphs, linear regression equations for EC, SAR and $\mathrm{pH}$ are presented. Regression lines for the different sampling points were statistically compared using the GenStat statistical package. When necessary, data were logarithmically transformed. Standard error about the regression line(s) are also shown.

\section{Results}

\section{Crocodile River catchment}

There is significant variability in river water EC with time at a point in the Crocodile River, with both the river water EC and temporal variability in EC increasing with distance downstream through the catchment (Fig. 2 and Table 3). At Karino, 
EC most often falls into the 'good' category (Table 1), while at Thankerton EC fluctuates between the 'good' and 'fair' categories. At Tenbosch, EC most often falls into the 'fair' category, and was even categorised as 'marginal' for brief periods during 2004 and 2005. This increase in EC as one moves downstream is a result of a combination of the increasing number of point source effluent discharges and non-point sources, including return flows from agriculture, along the course of the Crocodile River and its tributaries. Following the confluence of the Crocodile River with the Kaap River, total dissolved solids (TDS) concentrations have been observed to increase markedly, as the Kaap River drains an extensive area of active and abandoned gold mines (Deksissa et al., 2003). Worryingly, EC values measured in the Kaap River continue to increase steadily with time (Fig. 2), and EC for this river was consistently higher than for the Crocodile River measured at Thankerton, and most often higher than for the Crocodile River measured at Tenbosch. Regression lines were significantly different for the Karino and Tensbosch sampling points along the Crocodile River, and for the Kaap River and all sampling points along the Crocodile River (Karino, Thankerton, Tenbsoch). All regression line gradients differed significantly from zero.

For the Johnston (1976) study in which EC was measured between 1972 and 1974, measured EC at Tenbosch was observed to range from 13 to $63 \mathrm{mS} \cdot \mathrm{m}^{-1}$ with a mean value of $29 \mathrm{mS} \cdot \mathrm{m}^{-1}$. From 1983 to 1993, Meyer and Van Antwerpen (1995) observed that EC at Tenbosch ranged from 31 to 66 $\mathrm{mS} \cdot \mathrm{m}^{-1}$ with a mean value of $44 \mathrm{mS} \cdot \mathrm{m}^{-1}$. The overall mean for Tenbosch for the data used in this study is $48 \mathrm{mS} \cdot \mathrm{m}^{-1}$, showing a large increase (66\%) from the study done in 1976 and a smaller increase (9\%) from the study done in 1995. At Karino, mean EC values of 17 and $23 \mathrm{mS} \cdot \mathrm{m}^{-1}$ for the 1995 and current study, respectively, also show an increasing trend.

Similar to EC, the SAR increases as the Crocodile River runs its course (Table 3). At Karino, water quality for irrigation with regards to SAR always falls into the 'good' category. Mean seasonal values for Thankerton also always fall into the 'good' category, but for brief periods within seasons higher SAR levels result in water being categorised as 'fair'. At Tenbosch, water quality drifts between good and fair within seasons, but mean SAR falls into the 'good' category for all seasons except spring, when it is 'fair'. No change in SAR since pre-1993 levels has been observed at Karino, but, interestingly, mean SAR at Tenbosch has decreased from 2.0 for the 19831993 period to 1.3 in this study.

Spatially, there is a clear increase in $\mathrm{pH}$ from Karino to Thankerton to Tenbosh. At Karino, a temporal increase has been observed from 7.4 for the 1983-93 period to 7.6 for this study. The average $\mathrm{pH}$ at Tenbosch for the 1972-74, 198393 and 1999-2009 studies was 7.7, 8.0 and 8.2, respectively, showing a steady long-term increase in river water alkalinity at Tenbosch as well. Therefore any influences on river water $\mathrm{pH}$ resulting from acidic mine water draining into this river are potentially being countered by salts added via agricultural return flow resulting in a long-term increase in river alkalinity.

In contrast to EC, SAR and $\mathrm{pH}$, measured inorganic $\mathrm{N}$ and $\mathrm{PO}_{4}-\mathrm{P}$ concentrations were most often lower at Tenbosch than at Karino, with Thankerton having intermediate concentrations (Fig. 3). A similar trend was observed for the 1983-1993 period by Meyer and Van Antwerpen (1995). Very high $\mathrm{PO}_{4}-\mathrm{P}$ spikes were observed intermittently for Karino, especially for the period following 2006. The reason for this is unclear and warrants further investigation. Mean inorganic $\mathrm{N}$ levels have decreased since the 1983-1993 period at both Karino
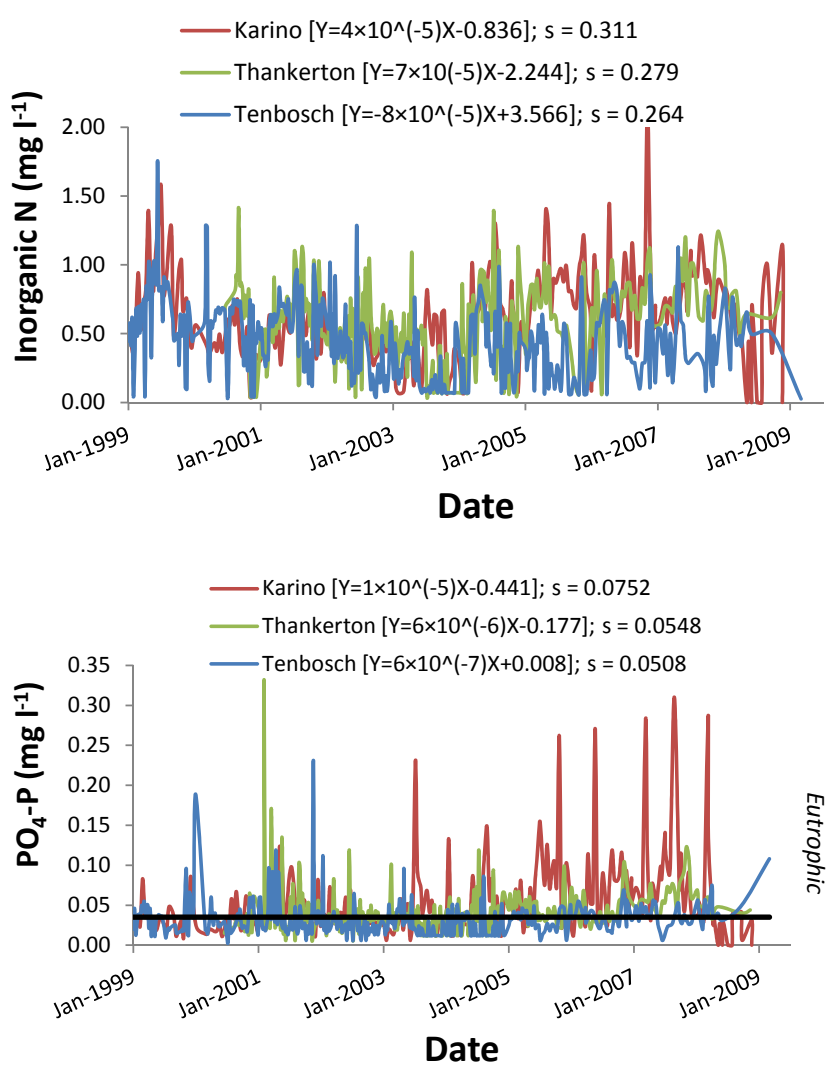

Figure 3

Crocodile River inorganic nitrogen ( $N$ ) (top) and phosphatephosphorus (PO4-P) (bottom) concentrations measured at Karino, Thankerton and Tenbosch for the period 1999-2009 (linear regression equations shown, $X=$ time, $Y=E C$; $s=$ standard error about the regression line).

$\left(1.15 \rightarrow 0.62 \mathrm{mg} \cdot \ell^{-1}\right)$ and Tenbosch $\left(0.67 \rightarrow 0.44 \mathrm{mg} \cdot \ell^{-1}\right)$, while very slight increases have been observed for $\mathrm{PO}_{4}-\mathrm{P}$ concentrations at these 2 sampling points.

\section{Komati-Lomati River catchment}

At Lomati, low EC levels result in this water being categorised as 'good' during all seasons for irrigation purposes (Table 4). Further downstream a sharp increase in EC is observed at the Komatipoort sampling point, where water is categorised only as 'fair' for irrigation purposes across all seasons. Electrical conductivity is highest during spring and winter at Komatipoort, and lowest in summer. The very high EC levels measured at Lomati during 2003 were most likely a result of the drought experienced in the region during this period (Faysse and Gumbo, 2004). Similar to the Crocodile River, there is a distinct increase in EC at the most downstream sampling point (Fig. 4). Regression lines differed significantly, although no significant difference between the gradients of the regression lines for Lomati and Komatipoort was observed.

Meyer and Van Antwerpen (1995) reported that the Komati River has a low salinity hazard $\left(<25 \mathrm{mS} \cdot \mathrm{m}^{-1}\right)$ and that small increases in salinity were observed since the study by Johnston (1976), when mean EC measured at Komatidraai (in close proximity to Komatipoort) for the $1972-74$ period was $16 \mathrm{mS} \cdot \mathrm{m}^{-1}$ (range: $12-27 \mathrm{mS} \cdot \mathrm{m}^{-1}$ ). However there has since been a significant increase in EC values for the Komati River, with a gross mean EC of $56 \mathrm{mS} \cdot \mathrm{m}^{-1}$ between 1999 and 2009 (present study). 
Similar to EC, SAR levels at Lomati result in the water being categorised as 'good' with regard to sodicity, but high SAR are observed intermittently at this point, placing quality in the 'fair' and even 'marginal' categories at certain times. Higher SAR at Komatipoort means that this water is categorised as 'fair' for spring, summer and winter, and 'good' during autumn. Higher differences between minimum and

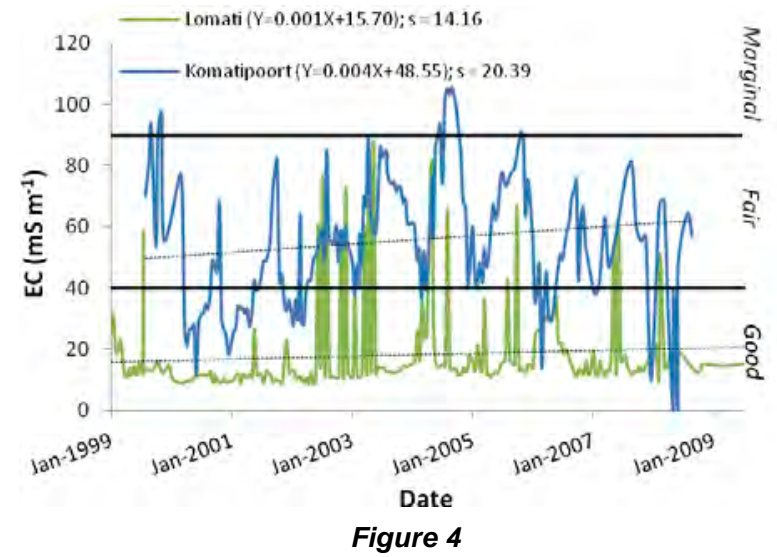

Lomati (measured at Lomati) and Komati (measured at Komatipoort) River electrical conductivity (EC) for the period 1999-2009 (black horizontal lines separate different salinity categories; linear regression equations also shown, $X=$ time,

$Y=E C ; s=$ standard error about the regression line). maximum SAR were measured upstream at Lomati than at Komatipoort. Mean SAR measured at Komatidraai for the 1972-1974 period was 0.77, ranging from 0.54-1.15, giving it a low sodicity hazard. This is the same rating as in the Meyer and Van Antwerpen (1995) study. Based on mean SAR values observed in this study, there is an increasing trend for SAR for the Komati River.

Inorganic $\mathrm{N}$ and $\mathrm{PO}_{4}-\mathrm{P}$ levels are similar at the Komatipoort and Lomati sampling points and relatively low, with mean $\mathrm{PO}_{4}$-P concentrations showing that this water is most often classified as mesotrophic.

\section{Pongola River catchment}

From an EC perspective, irrigation water quality is categorised as 'good' at Welgelegen for all seasons, but then deteriorates by the time it reaches Mhlati (Table 5) where it is categorised as 'good' for autumn only, and 'fair' for spring, summer and winter. For the study by Johnston (1976), the Pongola River was observed to have a mean EC of $62 \mathrm{mS} \mathrm{m}^{-1}$ and for the Meyer and Van Antwerpen (1995) study, while no mean values were reported, it was given a medium salinity hazard level (25-75 $\mathrm{mS} \cdot \mathrm{m}^{-1}$ ) and observed to have considerable temporal variability. A mean EC of $57 \mathrm{mS} \cdot \mathrm{m}^{-1}$ was observed at Mhlati for this study. Regression lines for Welgelegen and Mhlati were observed to differ significantly. The gradient for the Welgelegen regression line did not differ significantly from zero.

\begin{tabular}{|c|c|c|c|c|c|c|c|c|c|c|c|}
\hline \multicolumn{12}{|c|}{$\begin{array}{c}\text { TABLE } 4 \\
\text { Water quality data for the Lomati (measured at Lomati) and Komati (measured at Komatipoort) Rivers for the period } \\
1999-2009 .\end{array}$} \\
\hline \multirow{3}{*}{\multicolumn{2}{|c|}{ Paramaters }} & \multicolumn{10}{|c|}{ Komati-Lomati Catchment region } \\
\hline & & \multicolumn{5}{|c|}{ Lomati } & \multicolumn{5}{|c|}{ Komatipoort } \\
\hline & & Spring & Summer & Autumn & Winter & Annual & Spring & Summer & Autumn & Winter & Annual \\
\hline EC & Range & $9-67$ & $9-73$ & $9-60$ & $9-88$ & $9-88$ & 43-104 & $11-97$ & $22-70$ & $12-106$ & $11-106$ \\
\hline \multirow[t]{4}{*}{$\left(\mathrm{mS} \cdot \mathrm{m}^{-1}\right)$} & Mean & 14 & 16 & 17 & 21 & 18 & 72 & 51 & 43 & 60 & 56 \\
\hline & S.D. & 11 & 10 & 11 & 18 & 14 & 17 & 19 & 14 & 21 & 21 \\
\hline & Class & Good & Good & Good & Good & Good & Fair & Fair & Fair & Fair & Fair \\
\hline & & \multicolumn{5}{|c|}{$n=232$} & \multicolumn{5}{|c|}{$n=202$} \\
\hline \multirow[t]{5}{*}{ SAR } & Range & $0.3-2.8$ & $0.7-3.2$ & 0.3-1.8 & $0.3-3.1$ & $0.3-3.2$ & $1.3-2.4$ & $0.5-2.6$ & $0.7-2.4$ & $0.8-2.1$ & $0.5-2.6$ \\
\hline & Mean & 0.6 & 0.6 & 0.6 & 0.7 & 0.7 & 1.8 & 1.5 & 1.3 & 1.5 & 1.5 \\
\hline & S.D. & 0.5 & 0.4 & 0.3 & 0.6 & 0.5 & 0.4 & 0.5 & 0.4 & 0.4 & 0.4 \\
\hline & \begin{tabular}{|l|} 
Class \\
\end{tabular} & Good & Good & Good & Good & Good & Fair & Fair & Good & Fair & Fair \\
\hline & & \multicolumn{5}{|c|}{$\mathrm{n}=207$} & \multicolumn{5}{|c|}{$\mathrm{n}=178$} \\
\hline \multirow[t]{4}{*}{$\mathrm{pH}$} & Range & 7.5-8.3 & 7.3-8.4 & 7.3-8.3 & 6.9-8.6 & 6.9-8.6 & 8.1-8.9 & 7.2-9.3 & 7.2-8.9 & 7.1-8.8 & 7.1-9.3 \\
\hline & Mean & 7.7 & 7.8 & 7.8 & 7.8 & 7.8 & 8.4 & 8.3 & 8.1 & 8.3 & 8.3 \\
\hline & S.D. & 0.2 & 0.2 & 0.2 & 0.3 & 0.2 & 0.2 & 0.3 & 0.4 & 0.2 & 0.3 \\
\hline & & \multicolumn{5}{|c|}{$n=232$} & \multicolumn{5}{|c|}{$n=202$} \\
\hline \multirow{4}{*}{$\begin{array}{l}\mathrm{NO}_{3}+\mathrm{NO}_{2}-\mathrm{N} \\
\left(\mathrm{mg} \cdot \ell^{-1}\right)\end{array}$} & Range & $0.04-0.46$ & $0.02-1.46$ & $0.02-1.33$ & $0.02-1.59$ & $0.02-1.59$ & $0.02-0.77$ & $0.02-0.94$ & $0.04-1.23$ & $0.02-1.22$ & $0.02-1.23$ \\
\hline & Mean & 0.24 & 0.27 & 0.33 & 0.40 & 0.36 & 0.34 & 0.31 & 0.41 & 0.47 & 0.39 \\
\hline & S.D. & 0.099 & 0.28 & 0.35 & 0.29 & 0.29 & 0.29 & 0.23 & 0.25 & 0.28 & 0.27 \\
\hline & & \multicolumn{5}{|c|}{$\mathrm{n}=230$} & \multicolumn{5}{|c|}{$\mathrm{n}=202$} \\
\hline \multirow{4}{*}{$\begin{array}{l}\text { Inorganic } N \\
\left(\mathrm{mg} \cdot \ell^{-1}\right)\end{array}$} & Range & $0.03-0.50$ & $0.06-1.48$ & $0.03-1.35$ & $0.04-1.68$ & $0.03-1.68$ & $0.04-0.88$ & $0.04-0.99$ & $0.06-1.23$ & $0.04-1.29$ & $0.04-1.29$ \\
\hline & Mean & 0.29 & 0.32 & 0.38 & 0.45 & 0.48 & 0.38 & 0.36 & 0.46 & 0.51 & 0.44 \\
\hline & S.D. & 0.11 & 0.28 & 0.35 & 0.30 & 0.29 & 0.30 & 0.24 & 0.25 & 0.28 & 0.27 \\
\hline & & \multicolumn{5}{|c|}{$\mathrm{n}=232$} & \multicolumn{5}{|c|}{$\mathrm{n}=208$} \\
\hline \multirow[t]{4}{*}{$\begin{array}{l}\mathrm{PO}_{4}-\mathrm{P} \\
\left(\mathrm{mg} \cdot \ell^{-1}\right)\end{array}$} & Range & $\begin{array}{c}0.006- \\
0.050\end{array}$ & $\begin{array}{c}0.000- \\
0.086 \\
\end{array}$ & $\begin{array}{c}0.006- \\
0.081 \\
\end{array}$ & $\begin{array}{c}0.006- \\
0.384 \\
\end{array}$ & $\begin{array}{c}0.000- \\
0.384 \\
\end{array}$ & $\begin{array}{c}0.012- \\
0.070 \\
\end{array}$ & $\begin{array}{l}0.012- \\
0.094 \\
\end{array}$ & $\begin{array}{l}0.012- \\
0.088 \\
\end{array}$ & $\begin{array}{c}0.006- \\
0.304\end{array}$ & $\begin{array}{c}0.006- \\
0.304\end{array}$ \\
\hline & Mean & 0.019 & 0.021 & 0.023 & 0.029 & 0.024 & 0.026 & 0.030 & 0.036 & 0.033 & 0.031 \\
\hline & S.D. & 0.011 & 0.015 & 0.018 & 0.043 & 0.030 & 0.016 & 0.015 & 0.018 & 0.039 & 0.027 \\
\hline & & \multicolumn{5}{|c|}{$\mathrm{n}=232$} & \multicolumn{5}{|c|}{$\mathrm{n}=202$} \\
\hline
\end{tabular}

S.D. = standard deviation

$n=$ number of observations 

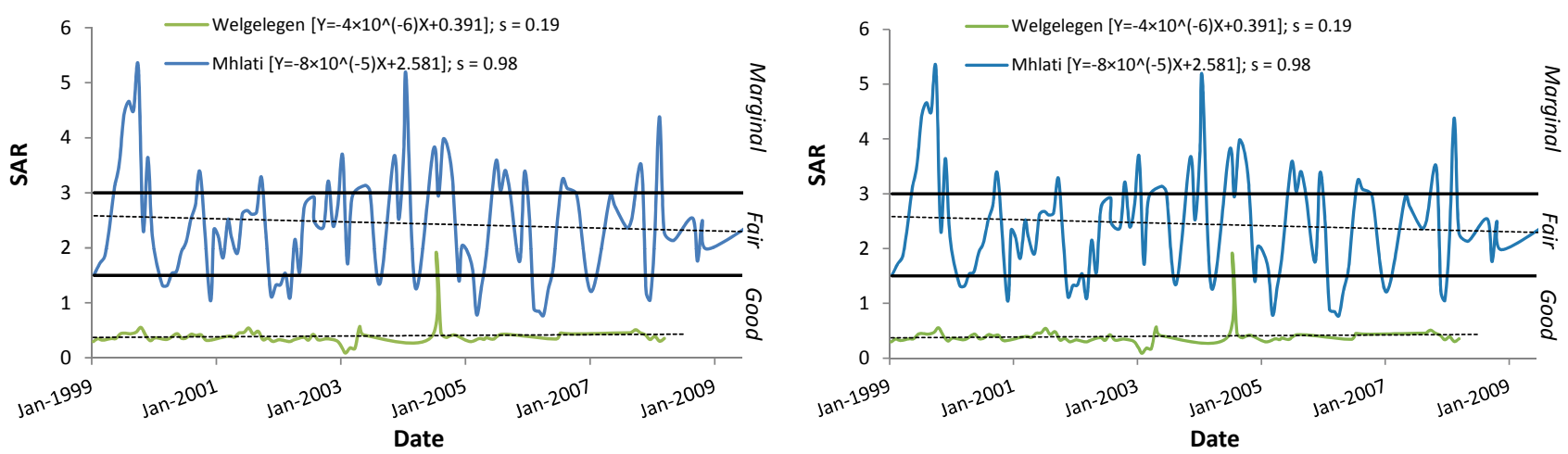

Figure 5

Bivane (measured at Welgelegen) and Pongola (measured at Mhlati) River electrical conductivity (EC) (left) and sodium adsorption ratio (SAR) (right) for the period 1999-2009 [black horizontal lines separate different salinity and sodicity categories; linear regression equations also shown, $X=$ time, $Y=E C$ (left) or SAR (right); $s$ = standard error about the regression line].

\begin{tabular}{|c|c|c|c|c|c|c|c|c|c|c|c|}
\hline & & & $\begin{array}{l}\text { Water qu } \\
\text { Pongola }\end{array}$ & $\begin{array}{l}\text { ity data } \mathrm{f} \\
\text { (measure }\end{array}$ & $\begin{array}{r}\text { TA } \\
r \text { the Biva } \\
\text { at Mhlati }\end{array}$ & $\begin{array}{l}3 \text { LE } 5 \\
\text { le (measu } \\
\text { Rivers fo }\end{array}$ & $\begin{array}{l}\text { ed at Wel } \\
\text { the perio }\end{array}$ & $\begin{array}{l}\text { elegen) a } \\
1999-200\end{array}$ & & & \\
\hline Paramaters & & & & & & Pongol & Region & & & & \\
\hline & & & & Welgelege & & & & & Mhlati & & \\
\hline & & Spring & Summer & Autumn & Winter & Annual & Spring & Summer & Autumn & Winter & Annual \\
\hline EC & Range & $9-16$ & 6-16 & $7-11$ & 8-55 & $6-55$ & $47-123$ & $20-123$ & $17-68$ & $25-112$ & $17-123$ \\
\hline$\left(\mathrm{mS} \cdot \mathrm{m}^{-1}\right)$ & Mean & 12 & 9 & 9 & 12 & 11 & 79 & 57 & 36 & 63 & 57 \\
\hline & S.D. & 2 & 2 & 2 & 8 & 6 & 24 & 26 & 17 & 20 & 24 \\
\hline & \begin{tabular}{|l|} 
Class \\
\end{tabular} & Good & Good & Good & Good & Good & Fair & Fair & Good & Fair & Fair \\
\hline & & & & $\mathrm{n}=78$ & & & & & $\mathrm{n}=104$ & & \\
\hline SAR & Range & $0.3-0.5$ & $0.1-0.6$ & $0.2-0.4$ & $0.3-1.9$ & $0.1-1.9$ & $1.8-5.3$ & $0.9-5.3$ & $0.8-2.9$ & $1.2-4.7$ & $0.8-5.3$ \\
\hline & Mean & 0.4 & 0.3 & 0.3 & 0.5 & 0.4 & 3.3 & 2.5 & 1.6 & 2.6 & 2.5 \\
\hline & S.D. & 0.06 & 0.09 & 0.06 & 0.3 & 0.2 & 1.0 & 1.1 & 0.7 & 0.8 & 1.0 \\
\hline & \begin{tabular}{|l|} 
Class \\
\end{tabular} & Good & Good & Good & Good & Good & Marginal & Fair & Fair & Fair & Fair \\
\hline & & & & $\mathrm{n}=76$ & & & & & $\mathrm{n}=104$ & & \\
\hline $\mathrm{pH}$ & Range & $7.2-8.1$ & $6.8-8.3$ & $6.4-7.8$ & $7.2-8.1$ & $6.4-8.3$ & $8.3-8.8$ & $7.0-8.8$ & 7.4-8.6 & 7.8-8.9 & $7.0-8.9$ \\
\hline & Mean & 7.8 & 7.6 & 7.4 & 7.8 & 7.7 & 8.6 & 8.3 & 8.1 & 8.4 & 8.4 \\
\hline & S.D. & 0.2 & 0.3 & 0.4 & 0.2 & 0.3 & 0.2 & 0.3 & 0.4 & 0.2 & 0.3 \\
\hline & & & & $\mathrm{n}=78$ & & & & & $\mathrm{n}=104$ & & \\
\hline $\mathrm{NO}_{3}+\mathrm{NO}_{2}-\mathrm{N}$ & Range & $0.02-0.39$ & $0.02-0.82$ & $0.02-0.51$ & $0.02-3.49$ & $0.02-3.49$ & 0.19-1.39 & $0.02-1.96$ & 0.04-1.08 & $0.06-1.20$ & $0.02-1.96$ \\
\hline$\left(\mathrm{mg} \cdot \ell^{-1}\right)$ & Mean & 0.19 & 0.28 & 0.16 & 0.32 & 0.27 & 0.71 & 0.60 & 0.44 & 0.71 & 0.62 \\
\hline & S.D. & 0.14 & 0.20 & 0.16 & 0.59 & 0.41 & 0.41 & 0.38 & 0.26 & 0.27 & 0.34 \\
\hline & & & & $\mathrm{n}=78$ & & & & & $\mathrm{n}=104$ & & \\
\hline Inorganic N & Range & $0.06-0.47$ & $0.04-0.84$ & $0.04-0.53$ & $0.04-3.53$ & $0.04-3.53$ & $0.26-1.41$ & $0.03-1.98$ & $0.06-1.29$ & $0.03-1.32$ & $0.03-1.98$ \\
\hline$\left(\mathrm{mg} \cdot \ell^{-1}\right)$ & \begin{tabular}{|l|} 
Mean \\
\end{tabular} & 0.24 & 0.34 & 0.20 & 0.36 & 0.31 & 0.75 & 0.63 & 0.50 & 0.72 & 0.65 \\
\hline & \begin{tabular}{|l|} 
S.D. \\
\end{tabular} & 0.16 & 0.20 & 0.20 & 0.59 & 0.41 & 0.41 & 0.38 & 0.31 & 0.31 & 0.35 \\
\hline & & & & $\mathrm{n}=78$ & & & & & $\mathrm{n}=104$ & & \\
\hline $\begin{array}{l}\mathrm{PO}_{4}-\mathrm{P} \\
\left(\mathrm{mg} \cdot \ell^{-1}\right)\end{array}$ & Range & $\begin{array}{c}0.031- \\
0.066\end{array}$ & $\begin{array}{c}0.006- \\
0.088\end{array}$ & $\begin{array}{c}0.006- \\
0.050\end{array}$ & $\begin{array}{c}0.006- \\
0.402\end{array}$ & $\begin{array}{c}0.006- \\
0.402\end{array}$ & $\begin{array}{c}0.006- \\
0.027\end{array}$ & $\begin{array}{c}0.006- \\
0.094\end{array}$ & $\begin{array}{c}0.016- \\
0.211\end{array}$ & $\begin{array}{c}0.006- \\
0.344\end{array}$ & $\begin{array}{c}0.006- \\
0.344\end{array}$ \\
\hline & Mean & 0.015 & 0.028 & 0.023 & 0.044 & 0.032 & 0.018 & 0.028 & 0.057 & 0.036 & 0.035 \\
\hline & \begin{tabular}{|l|} 
S.D. \\
\end{tabular} & 0.007 & 0.016 & 0.013 & 0.071 & 0.048 & 0.006 & 0.017 & 0.062 & 0.059 & 0.045 \\
\hline & & & & $\mathrm{n}=78$ & & & & & $\mathrm{n}=104$ & & \\
\hline
\end{tabular}

S.D. = standard deviation

For the Jozini Dam downstream of the irrigated region in Pongola, water quality has been reported as ideal but showing deterioration with regards to salinity, and this increase in salinity is attributed to irrigation return flows (DWA, 2009). From Fig. 5, a decreasing trend for EC at Mhlati is apparent, which somewhat contradicts findings for the Department of Water Affairs study mentioned above. This may be influenced by the differing intensity of measurements affecting mean values.
At Welgelegen, EC values have remained very stable over the 1999-2009 period, confirming the good quality of this water from a salinity perspective.

Sodium Adsorption Ratio measured at Welgelegen was very low and resulted in irrigation water at this point consistently being categorised as 'good'; SAR is observed to increase rapidly downstream, however (Fig. 5), and at Mhlati the quality is 'fair' during summer, autumn and winter, and 'marginal' 


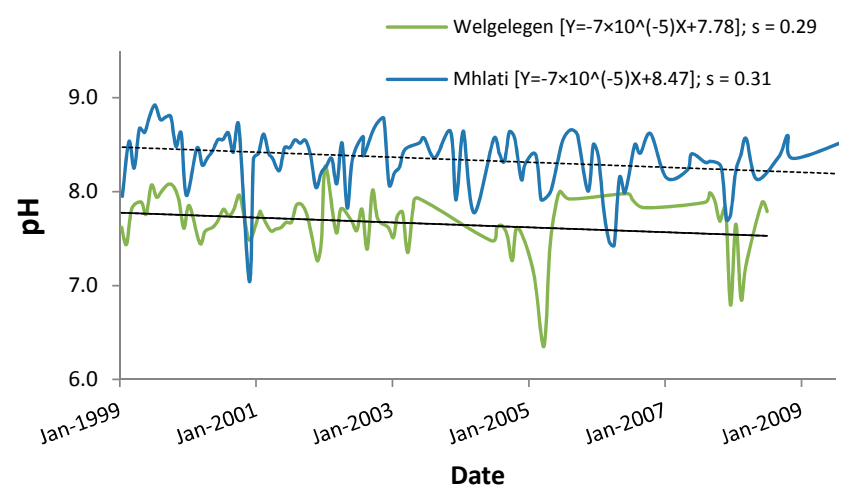

Figure 6

Bivane (measured at Welgelegen) and Pongola (measured at Mhlati) River $\mathrm{pH}$ for the period 1999-2009

(linear regression equations also shown, $X=t i m e, Y=p H$; $s=$ standard error about the regression line)

during spring. As river flow is potentially lowest during winter and spring, this increase in SAR is most likely due to increased precipitation of $\mathrm{Ca}$ and $\mathrm{Mg}$ (which will occur when bicarbonates, $\mathrm{Ca}$ and $\mathrm{Mg}$ are present and water $\mathrm{pH}$ is above 8.3 (Richards, 1954)) rather than an increase of Na. Regression lines differed significantly for the 2 sampling points but there was no significant difference between the regression line gradients and zero (Fig. 5).

DWA (2009) reported that 'acid mine drainage from old coal mines in the Paulpietersburg (in the upper part of the Pongola River catchment) area is affecting local streams but not the main stem Bivane or Pongola Rivers'. At both the Welgelegen and Mhlati sampling points there is a strong decreasing trend in $\mathrm{pH}$, however, which is cause for concern and requires action to stop this downward trend (Fig. 6). Although the regression lines differed significantly from each other, there was no significant difference between the gradients of the regression lines for the 2 sampling points.

An increase in inorganic $\mathrm{N}$ concentration from Welgelegen to Mhlati can clearly be observed in the data. There is however no such trend for $\mathrm{PO}_{4}-\mathrm{P}$. Eutrophication at the inflow of the Jozini Dam is attributed to nutrient enrichment via irrigation return flows, and concerns have been raised regarding a new invasive water plant, Hydrilla verticilata, which is feeding on this enrichment (DWA, 2009). At the sampling points considered here, however, $\mathrm{PO}_{4}-\mathrm{P}$ concentrations were most often below eutrophic levels.

\section{Discussion}

River water EC data consistently show an increase in salt concentrations as the rivers run their course. Drainage basin lithology and weathering stoichiometry are the primary controls of the chemistry of unpolluted rivers, and this is modified drastically by anthropogenic activities, changing land-use patterns and a changing climate (De Villiers, 2005). The observed increase in EC is a result of high anthropogenic inputs along the river course and river water evaporation which leads to a concentration of salts. Forestry can be expected to greatly reduce the dilution capacity of the rivers, and irrigated agriculture will reduce the dilution capacity as well as potentially add significant quantities of salt to the rivers via return flows. In addition, increases in EC over time are clearly evident for rivers in the Crocodile and Komati-Lomati River catchments, and action is required to reverse this concerning trend.

The contribution of specific human activities as well as natural geological processes to river salt load is extremely difficult to quantify. As our catchments become more developed and intensively managed the relative contribution of natural processes will be greatly reduced. For the Crocodile River, for example, the contribution of geological processes such as chemical weathering has been estimated to be far less $(<1 \%)$ than contributions from soil erosion and land use (DWAF, 1995).

Considering the vast amount of mining activities taking place in the Crocodile River catchment, a decreasing trend in river water $\mathrm{pH}$ reflecting the acidifying effect of acid mine drainage on the Crocodile River was expected. The $\mathrm{pH}$ data, however, show the opposite trend. Our hypothesis is that the addition of salts into the system from irrigation return-flow is countering the effects of acid mine drainage.

Evidence of nutrient enrichment in the rivers analysed is apparent. Interestingly for the Crocodile River, higher nutrient enrichment is observed upstream compared with downstream. The reason for the decrease in inorganic $\mathrm{N}$ and $\mathrm{PO}_{4}-\mathrm{P}$ concentrations as one moves downstream is not clear, but may be a result of instream processes such as carbon metabolism, sedimentation, bacteria-mediated species transformation and denitrification - all of which can cause variations in nutrient forms during the transport process (Downing, 1997; Behrendt and Opitz, 1999; Brodie and Mitchell, 2005). It is common that river monitoring programmes tend to focus on inorganic determinants such as total oxidisable $\mathrm{N}\left(\mathrm{NO}_{3}^{-}+\mathrm{NO}_{2}^{-}\right), \mathrm{NO}_{3}^{-}, \mathrm{NH}_{4}^{+}$ and soluble reactive phosphorus $\left(\mathrm{PO}_{4}^{3-}\right)$, based on the assumption that the inorganic forms are the key fractions available to organisms in freshwaters (Heathwaite and Johnes, 1996). This can be inadequate for catchments in which large quantities of nutrients reach waterways in organic form or for water systems where transformations lead to significant organic fractions being present. Heathwaite and Johnes (1996), for example, observed that $\mathrm{N}$ in organic form was an important secondary constituent of $\mathrm{N}$ flow in streams and recommended that all forms of $\mathrm{N}$ should be monitored to gain a full understanding of environmental fluxes. The same may well apply for $\mathrm{P}$, requiring analysis for organic and sediment-bound P. It may also be plausible that $\mathrm{N}$ and $\mathrm{PO}_{4}-\mathrm{P}$ concentrations are reduced as a result of uptake by crops when these nutrients are added to the land via irrigation water.

In many cases sharp spikes were observed for inorganic $\mathrm{N}$ and/or $\mathrm{PO}_{4}-\mathrm{P}$, but reasons for these spikes are still unclear and in need of further investigation. First flush phenomenon, in which higher pollutant loadings occur in the first few storm events of a season, as has been observed for urban runoff (Soller et al., 2005), could be an important factor. Spikes of this nature are not observed in data preceding 1999 (data not shown), however, and may be attributed to ageing infrastructure and/or insufficient or inappropriate maintenance and upgrade programmes at wastewater treatment works, amongst other things, within these catchments.

The problem of water pollution is not the exclusive responsibility of governments, however, and everybody, including agriculturalists, has a responsibility to reduce emissions through improved management practices. In addition to salinity and sodicity management in the root zone, irrigators also have an important role to play in minimising salt return flows to rivers. While the leaching of salt from the root zone is essential to meet productivity objectives, unplanned over-irrigation and leaching of applied fertilisers should be minimised, and 
preferably eliminated. The adoption of more efficient irrigation practices, such as drip irrigation, will potentially lower water extraction from the rivers resulting in a greater dilution capacity. Wetlands and natural vegetation buffer strips have been observed to very efficiently remove pollutants from agricultural return flows (Barling and Moore, 1994; Reddy and Gale, 1994). Drainage water from cropping systems can also be re-used or carefully disposed of, for example, through discharge into evaporation lakes to reduce pollution of natural waterways (Beltrán, 1999). This type of ecological and man-made infrastructure should be considered for inclusion into all land-use plans, and is especially important when cultivated fields are located in close proximity to watercourses.

Based on the results of this scoping study we offer the following recommendations to improve our understanding and ability to manage water quality in these catchments:

- River flow measurements need to be made at the same locations as chemical water quality measurements to enable the determination of pollutant loads.

- Increased measurement of organic forms of $\mathrm{N}$ and $\mathrm{P}$, chemical/biological oxygen demand as well as other harmful compounds such as pesticides is needed.

- An ecological risk assessment that objectively ranks the risk of individual pollutants will be a critical first step to ensure targeted management for the right pollutants (Jones et al., 2005; Kroon and Brodie, 2009).

- More focused and detailed studies on river water chemistry using DWA datasets are required. For example, the presence of bicarbonates of $\mathrm{Ca}_{2}{ }^{+}$and $\mathrm{Mg}_{2}{ }^{+}$may indicate the contribution of mineral weathering to river salt load in the catchment (Conyers et al., 2008). Distinguishing between $\mathrm{Cl}^{-} / \mathrm{Na}^{+}$dominated streams and $\mathrm{Ca}_{2}{ }^{+}, \mathrm{Mg}_{2}{ }^{+} / \mathrm{HCO}_{3}{ }^{-}$streams also allows for refined searches for sources of more soluble salts (e.g. $\mathrm{K}, \mathrm{Na}, \mathrm{Cl}$ which will concentrate to higher EC and cause greater osmotic stress) that will potentially worsen with time (Conyers et al., 2008). Relatively high concentrations of $\mathrm{SO}_{4}^{2-}$ in rivers (as observed for the Kaap River) is indicative that they are most likely receiving high levels of acid mine drainage, as this type of drainage is rich in this anion.

- Development of a conceptual framework linking river pollutant levels to the catchment activities responsible, enabling multi-stakeholder buy-in and including thresholds for action. This will be essential to help reverse the current negative trends in water quality.

- Identification of high priority areas or 'hot-spots' which should be earmarked for the implementation of control policies.

\section{Conclusions}

South African DWA river water quality data are extremely useful to assess irrigation water quality and to monitor longterm trends, as shown in this study. Relatively good water quality for irrigation purposes is available for the Crocodile River, Komati-Lomati and Pongola River catchments. Signs of long-term deterioration in river water quality are clear, as is expected for catchments with intensifying anthropogenic impacts. Solute concentrations, as represented by EC measurements, clearly increase further downstream and irrigators located lower in the catchments should adjust management practices accordingly. An additional sodicity hazard is posed for the lower regions of the Pongola River catchment. Nutrient ( $\mathrm{N}$ and $\mathrm{P}$ ) enrichment is evident for almost all of the sampling points analysed. These data can also be used to obtain insights into the contribution of different anthropogenic activities to water pollution, but high spatial and temporal variation makes interpretation challenging. Furthermore, the potential exists to use this information to inform upstream dam releases to achieve suitable pollutant dilution in the rivers (Deksissa et al., 2003). Such an approach will, however, be most appropriate for and help ecosystems sensitive to 'concentration' of particular pollutants as opposed to those sensitive to total pollution load, and will not necessarily encourage fixing the pollution problem at the source.

Additional intensified monitoring is recommended to enhance decision making from the farm to catchment level based on improved temporal and spatial river water quality data. Based on findings made in this scoping study, recommendations for future studies have now been made. Further scoping studies of this nature are recommended for other major or vulnerable catchments across South Africa.

\section{Acknowledgements}

The authors thank the Department of Water Affairs for access to their data for this study. Comments from Mr Francois Olivier, Dr Annett Weigel, Dr Peter Thorburn and Dr Zahra Paydar helped us improve this paper. The authors are also grateful to Mrs Ingrid Mthembu for the GIS maps and Miss Nikki Sewpersad for assistance with statistical analyses.

\section{References}

BARLING RD and MOORE ID (1994) Role of buffer strips in management of waterway pollution: A review. Environ. Manage. 18 543-558.

BEHRENDT H and OPITZ D (1999) Retention of nutrients in river systems: dependence on specific runoff and hydraulic load. Hydrobiologia 410 111-122.

BELTRÁN JM (1999) Irrigation with saline water: benefits and environmental impacts. Agric. Water Manage. 40 183-194.

BRICKER OP and JONES BF (1995) Main factors affecting the composition of natural waters. In: Salbu Band Steinnes E (eds.) Trace Elements in Natural Waters. CRC Press, Boca Raton. 1-5.

BRODIE JE and MITCHELL AW (2005) Nutrients in Australian tropical rivers: changes with agricultural development and implications for receiving environments. Mar. Freshwater Res. 56 279-302.

CONLEY AH (1996) A synoptic view of water resources in South Africa. Monograph 6: Sink or SWIM. Department of Water Affairs and Forestry, Pretoria.

CONYERS MK, HUME, SUMMERELL G, SLINGER D, MITCHELL $M$ and CAWLEY R (2008) The ionic composition of the streams of the mid-Murrumbidgee River: Implications for the management of downstream salinity. Agric. Water Manage. 95 598-606.

DEKISSA T, ASHTON PJ and VANROLLEGHEM (2003) Control options for river water quality improvement: A case study of TDS and inorganic nitrogen in the Crocodile River (South Africa). Water SA 29 209-217.

DWAF (DEPARTMENT OF WATER AFFAIRS AND FORESTRY, SOUTH AFRICA) (1995) Water Quality Management Series. Crocodile River Catchment Eastern Transvaal. Water Quality Situation Assessment. Volumes 1-9. Department of Water Affairs and Forestry, Pretoria.

DWAF (DEPARTMENT OF WATER AFFAIRS AND FORESTRY, SOUTH AFRICA) (1996) South African Water Quality Guidelines. Volumes 1-4. Department of Water Affairs and Forestry, Pretoria.

DWAF (DEPARTMENT OF WATER AFFAIRS AND FORESTRY, SOUTH AFRICA) (2004) Internal Strategic Perspectives: Inkomati Water Management Area - Version 1. Prepared by Tlou \& Matji (Pty) Ltd, Report No. P WMA 05/000/00/0303. Department of Water Affairs and Forestry, Pretoria. 
DWA (DEPARTMENT OF WATER AFFAIRS, SOUTH AFRICA) (2009) Adopt-a-River Programme Phase II: Development of an Implementation Plan. Water Resource Quality Situation Assessment. Prepared by H Hendriks and JN Rossouw for Department of Water Affairs, Pretoria, South Africa.

DOWNING JA (1997) Marine nitrogen:phosphorus stoichiometry and the global N:P cycle. Biogeochemistry 37 237-252.

FAYSSE N and GUMBO J (2004) The transformation of irrigation boards into water user associations in South Africa: Case studies of the Umlaas, Komati, Lomati and Hereford irrigation boards. Working Paper 73, Volume 2. International Water Management Institute, Colombo, Sri Lanka.

HEATHWAITE AL and JOHNES PJ (1996) Contributions of nitrogen species and phosphorus fractions to stream water quality in agricultural catchments. Hydrol. Process. 10 971-983.

HEEG J and BREEN CM (1982) Man and the Pongola floodplain. South African National Scientific Programmes Report No. 56. CSIR, Pretoria.

JOHNSTON MA (1976) River water quality in the northern sugar areas. Proc. S. Afr. Sugar Technol. Ass. 50 90-97.

JONES M, STAUBER J, APTE S, SIMPSON S, VINCENT-BECKETT V, JOHNSON R and DUIVENVOORDEN L (2005) A risk assessment approach to contaminants in Port Curtis, Queensland, Australia. Mar. Poll. Bull. 51 448-458.

KOEGELENBERG FH (2004) Irrigation User's Manual - Chapter 5: Water. Agricultural Research Council, Silverton, South Africa.

KROON FJ and BRODIE J (2009) Catchment management and health of coastal ecosystems: synthesis and future research. Mar. Freshwater Res. 60 1196-1200.

MACKAY HM, ROUX DJ, ASHTON PJ, VAN VLIET HR and JOOSTE S (1995) The development of South African water quality guidelines for the natural aquatic environment. Water Sci. Tech. 32 293-299.

MATSON PA, PARTON WJ, POWER AG and SWIFT MJ (1997) Agricultural intensification and ecosystem properties. Science 277 504-509.

MEYER JH and VAN ANTWERPEN R (1995) Trends in water quality of selected rivers in the South African sugar industry. Proc. S. Afr. Sugar Technol. Ass. 69 60-68.
OECD (ORGANISATION FOR ECONOMIC COOPERATION AND DEVELOPMENT) (1982) Eutrophication of waters: monitoring, assessment and control. Technical Report, OECD, Paris.

OLBRICH BW and HASSAN R (1999) A comparison of the economic efficiency of water use of plantations, irrigated sugarcane and sub-tropical fruits: A case-study of the Crocodile River Catchment, Mpumalanga province. WRC Report No. 666/1/9. Water Research Commission, Pretoria.

PEIERLS BL, CARACO NF, PACE ML and COLE JJ (1991) Human influence on river nitrogen. Nature 350 386-387.

REDDY KR and GALE PM (1994) Wetland processes and water quality: A symposium overview. J. Environ. Qual. 23 875-877.

RHOADES JD (1974) Drainage for salinity control. In: J van Schilfgaarde (ed.) Drainage for Agriculture. Agronomy Monograph No. 17. SSSA, Madison. 433-461.

RICHARDS LA (1954) Diagnoses and improvement of saline and alkali soils. Agriculture Handbook No. 60. United States Department of Agriculture, Washington. 160 pp.

SHRESTHA A and KAZAMA F (2007) Assessment of surface wate quality using multivariate statistical techniques: A case study of the Fuji river basin, Japan. Environ. Model. Softw. 22 464-475.

SOLLER J, STEPHENSON J, OLIVIERI K, DOWNING J and OLIVIERI AW (2005) Evaluation of seasonal scale first flush pollutant loading and implications for urban runoff management. J. Environ. Manage. 76 309-318.

SUAREZ DL, WOOD JD and LESCH SM (2006) Effect of SAR on water infiltration under a sequential rain-irrigation management system. Agric. Water Manage. 86 150-164.

TLOU and MALLORY (2006) Socioeconomic Consequences Report. Komati Catchment Ecological Water Requirements Study. DWAF Report No. RDM X100-00-CON-COMPR2-1405Department of Water Affairs and Forestry, Pretoria.

WALMSLEY RD (2000) Perspectives on eutrophication of surface waters: policy/research needs in South Africa. WRC Report No. KV129/00. Water Research Commission, Pretoria.

YOUNG WJ, MARSTON FM and DAVIS JR (1996) Nutrient exports and land use in Australian Catchments. J. Environ. Manage. 47 165-183. 